\title{
Interleukin-6 neutralization alleviates acute exacerbation-like disease in a model of cigarette smoke-induced pulmonary inflammation
}

\author{
John Kubera ${ }^{1 *}$, Katherine Hammerman ${ }^{2}$, Cara MM Williams ${ }^{1}$, Cedric Hubeau ${ }^{1}$ \\ From 2nd Cross Company Respiratory Symposium \\ Horsham, UK. 6-7 September 2012
}

Increased systemic and pulmonary levels of interleukin (IL) -6 have been associated with the severity of acute exacerbations and accelerated decline of lung function in COPD patients. The demonstration that IL-6 plays a pivotal role in AE-related pulmonary symptoms and therefore represents a therapeutic target for the treatment of COPD, remains elusive. We used a murine model where $\mathrm{C} 57 \mathrm{BL} / 6$ female mice are exposed to cigarette smoke (CS) twice daily through a nose-only system, while being punctually challenged intranasally with poly I:C, a synthetic ligand for Toll Like Receptor-3 (TLR3). This protocol recapitulates several aspects of pulmonary inflammation as seen in acute exacerbations of COPD, including prominent airway neutrophilia as well as increased levels of type I interferon, GM-CSF, IL-6, KC, MIP-1 alpha, RANTES, and TNFalpha in bronchoalveolar lavage (BAL) samples. Using this model, IL-6 deficient mice showed a susceptibility to CSinduced pulmonary inflammation that, overall, was comparable to that found with wild-type (WT) control mice. In contrast, using the same model with WT mice treated intraperitoneally with IL-6 neutralizing antibodies (rat IgG1, clone MP5-20F3, $25 \mathrm{mg} / \mathrm{kg}$ thrice weekly) diminished blood counts of lymphocytes $(\mathrm{p}=0.0070)$ and monocytes $(\mathrm{p}=0.0091)$, while this treatment also depleted BAL levels of IL- $6(p=0.0002)$ and reduced BAL levels of KC $(p=0.0220)$. Total BAL cellularity was found to be largely decreased ( $p<0.0001)$ as well as BAL numbers of neutrophils $(\mathrm{p}=0.0031)$, lymphocytes $(\mathrm{p}<0.0001)$ and macrophages $(\mathrm{p}<0.0001)$, while inflammatory infiltrates seemed reduced in lung tissue sections from treated mice. Our results show that the neutralization of IL-6 largely abrogates pulmonary inflammation in CS-exposed mice, and

IInflammation and Remodeling, Pfizer Cambridge, Massachusetts, 02140, USA Full list of author information is available at the end of the article therefore indicate that IL- 6 may be a valid therapeutic target for the treatment of COPD, in particular in episodes of acute exacerbation.

\section{Authors' details}

'Inflammation and Remodeling, Pfizer Cambridge, Massachusetts, 02140, USA. ${ }^{2}$ Drug Safety R\&D, Pfizer Cambridge, Massachusetts, 02140, USA.

Published: 14 August 2013

\section{doi:10.1186/1476-9255-10-S1-P33}

Cite this article as: Kubera et al:: Interleukin-6 neutralization alleviates acute exacerbation-like disease in a model of cigarette smoke-induced pulmonary inflammation. Journal of Inflammation 2013 10(Suppl 1):P33.

Submit your next manuscript to BioMed Central and take full advantage of:

- Convenient online submission

- Thorough peer review

- No space constraints or color figure charges

- Immediate publication on acceptance

- Inclusion in PubMed, CAS, Scopus and Google Scholar

- Research which is freely available for redistribution 